\title{
THE IMAGE OF RUSSIA AND RUSSIANS AS SEEN BY POLISH UNIVERSITY STUDENTS
}

\author{
Alina Awramiuk-Godun \\ Institute of Socio-Economic Geography and Spatial Management, University of Warsaw, Poland \\ TOMASZ WiTES \\ Institute of Regional and Global Studies, University of Warsaw, Poland
}

Manuscript received: 18 August 2012

Revised version: May 15, 2013

Awramiuk-Godun A. \& Wites T., 2013. The image of Russia and Russians as seen by Polish university students. Quaestiones Geographicae 32(2), Bogucki Wydawnictwo Naukowe, Poznań, pp. 91-103. 6 figs. DOI 10.2478/quageo-2013-0016, ISSN 0137-477X.

ABSTRACT. The results presented in this study are part of a joint research project undertaken in 2011 by the University of Warsaw and the University of St. Petersburg entitled "The perception of Polish-Russian relations by students in Poland and Russia". The main purpose of the research conducted in Poland was to investigate the beliefs and attitudes of students at the University of Warsaw toward Russia and Russians. Students are open to the surrounding reality, conscious of the mental and spatial proximity that links Poles and Russians, and aware of the problems that define the present-day Polish-Russian relations. A vast majority of participants are people who possess a fairly extensive knowledge of various aspects of life in Russia and express sympathy for Russia and Russian people. In the opinion of the authors, the results of the above study can be useful to teachers at universities, especially those that deal with European, socio-cultural and geographical subjects.

KEY wORDS: students' attitudes, Russia and Russians, University of Warsaw, questionnaire survey

Alina Awramiuk-Godun, Institute of Socio-Economic Geography and Spatial Management, Faculty of Geography and Regional Studies, University of Warsaw, ul. Krakowskie Przedmieście 30, 00-927 Warsaw, Poland; e-mail:alina.awramiuk@ uw.edu.pl

Tomasz Wites, Institute of Regional and Global Studies, Faculty of Geography and Regional Studies, University of Warsaw, ul. Krakowskie Przedmieście 30, 00-927 Warsaw, Poland; e-mail: t.wites@uw.edu.pl

\section{Introduction}

The study of mutual perception among nations is an important indicator of the bilateral state of the political, economic and cultural relations between countries. Often, the image of a nation in the eyes of another is the result of histori- cal circumstances that, to varying degrees, affect the current state of the relationship. The image of a country and its nation as it appears to the people of another state plays a very important role in determining the nature of the relationship between them at various levels - high (national) and everyday (societal). This image is so impor- 
tant in forming current policies and interpersonal contacts that many countries conduct regular public opinion surveys on how specific countries and people are perceived. They are often undertaken in the political and economic context of major international events, such as visits of heads of state, the conclusion of agreements on economic cooperation, etc.

Due to its turbulent history and fluctuating participation in the hierarchy of the world, Russia remains of interest to representatives of many nations. The new frame of reference for how Russia is perceived is related to an attempt to determine the place and role of Russian people in Europe in terms of political, socio-economic and cultural backgrounds.

In his book Resurrection: The struggle for a new Russia, David Remnick presents the circumstances under which European countries see Russia, and identifies a number of characteristics that define the attitude of the Russian people toward Europe. According to the author, Russians show intellectual respect, jealousy, admiration and the desire to compete. In the eyes of the Russians, the West is well organised and efficient, but at the same time fake, cold, calculated, self-absorbed and incapable of great accomplishments and real emotions.

How Russia and Russians are perceived in Europe depends on many factors, such as geographical proximity, historical relations, economic co-dependence, and social ties. The perception of Russia and Russians varies across nations, but also across social groups. This article seeks to present how Russia and Russians are perceived by academic youth in Poland. The element that ties the study together will be a discussion of the different approaches in the evaluation of Russians by representatives of various countries and of how these countries are perceived by Russians.

Polish-Russian relations have been a subject of interest to many Polish and Russian researchers of various disciplines, such as philosophy, sociology, political science, history and linguistics (Berdyaev 1916, Kral 2006, Bugajski 2010). This topic has also been repeatedly addressed by institutions involved in public opinion surveys in Poland and in Russia. In 2001, a joint study was undertaken by the Polish Information Agency (PAI) in collaboration with the Russian news agency Novosti (Orłowski 2006). For many years, the Centre for Public Opinion Research (CBOS) has been conducting regular surveys of how the Polish community evaluates Polish-Russian relations. These studies have become particularly relevant after the crash of the presidential plane near Smolensk in 2010.

Polish-Russian prejudices affect the stereotypical perception of Russia by Poles and Poland by Russians, and have an important place in the conducted studies of relations between the two countries. Many researchers (such as de Lazari 2006, Skorupska 2006, Bugajski 2010) blame the media for this persisting negative attitude of Polish society toward Russia and Russians and their methods of reporting and commenting on the political, economic and social situation in Russia. The media are the main and often the only provider of knowledge about the world.

Andrzej de Lazari - a political scientist, historian of philosophy and thought, expert on the Soviet Union and Russia - gives much attention in his works $(2004,2006)$ to this vast and extremely complicated problem of Polish-Russian relations. He is the author and editor of many scientific papers and magazine articles concerning the mechanisms of formation of the stereotypical and negative images in the minds of both nations. He also seeks to understand and explain the causes and consequences of Russophobia and Polonophobia (xenophobia directed at Russians and Poles) present in both societies.

\section{Purpose and scope of research}

The results presented in this study are part of a joint research project undertaken in 2011 by the staff of the Department of Geography and Regional Studies at the University of Warsaw and scholars in the Department of Geography and Geoecology at the University of St. Petersburg entitled "The perception of Polish-Russian relations by students in Poland and Russia".

The main purpose of the research conducted in Poland was to investigate the beliefs and attitudes of students at the University of Warsaw (UW) toward Russia and Russians. From the perspective of the study, it was equally important to learn how the UW students saw the relationship between the two countries. 
One of the first important stages of the research procedures was to choose a proper and standardised technique for obtaining data on the subject of study. The researchers decided that they would conduct the survey in full awareness of the limitations of this technique in terms of acquiring and storing information. Among the disadvantages of this approach were limited power they had in the selection of respondents and the limited possibility of addressing the multi-faceted issues related to phenomena that occur in different spheres of social life, but only indirectly affect the beliefs and attitudes of the UW students towards Russia and Russians.

Opinions about the reliability of the information obtained via surveys are divided. Proponents of surveys as a research tool point out that people tend to respond more exhaustively and honestly in a situation where there is no direct recipient of their statements (the interviewer). On the other hand, opponents believe that the responses obtained in this way are not spontaneous, are more formal and therefore less sincere. Because psychological defence mechanisms are not very active while answering survey questions, people rarely express what they really think (Sztabiński 1997).

The present authors, aware of the advantages and disadvantages of this technique, decided that the survey, conducted in May 2011, was valid. It was carried out among students majoring in various fields and from various departments of the University of Warsaw. A questionnaire was used to identify the beliefs of those surveyed. Developed jointly with the Russians, it consisted of 13 questions, including eight closed-ended ones, five open-ended ones, and three biographical ones about the age, gender and field of study. Closed-ended questions focused on respondents' assessment of Polish-Russian relations and their ideas about Russia and the Russian people; the respondents were asked, among others, to choose from the list of provided terms or statements those that they associated with Russia and the traits they would assign to Russians. In the open-ended questions they were asked to name famous Russian scientists, artists, politicians, athletes, interesting objects, natural and cultural sites, and to determine what, in their opinion, affected positively and negatively the nature of Polish-Russian relations.
The survey design and the closed-ended and open-ended questions it contained made it possible to collect a significant amount of information on the subject.

\section{Profile of the respondents}

The study was conducted among 123 University of Warsaw students, 81 female $(66 \%)$ and 42 male $(34 \%)$. The age of the respondents ranged from 20 to 29 , with $90 \%$ aged between 20 and 24 years. 23-year-old students were most numerous (35 individuals, making up $28 \%$ of the surveyed group).

The University of Warsaw is one of the biggest universities in Poland. It is an academic centre with a long tradition, repeatedly ranked at the top of public universities in the country. The study was conducted among attendees of elective classes, such as Cultural Borders and the Geography of Russia, held in the UW Department of Geography and Regional Studies building. Students choose their electives from a list proposed by various departments. Those classes help them to develop their own interests and deepen their knowledge of the subject.

The survey participants included science majors, such as Biology, Biotechnology and Geology, Mathematics and Economics majors, as well as humanities majors, such as Polish Philology, Spanish and Portuguese Studies, and Russian Studies.

The respondents most commonly represented the following majors: Geography (22 persons, or $18 \%$ ), History (17 persons, or 14\%), Philology, including English, Germanic and Russian Studies (16 persons, or 13\%) and Spatial Management (11 persons, or $9 \%$ ). The large number of Geography and Spatial Management students is due to the fact that the survey was carried out during elective classes in the Department of Geography and Regional Studies.

20 respondents in the surveyed group (16\%) represented fields of study related to broader European subjects (including East European Studies, European Studies, East Slavic European Studies, and International Relations). Other participants were enrolled in Cultural Studies (4 persons), Economics (4), Science (3), Psychology 
(3), Sociology (3), Mathematics (2), and Law (2 persons). Although this group of students did not represent the full diversity of the fields of study offered at the University, it was still possible to capture some differences in their attitudes and views about Russia by their education profile.

Information about direct experience and personal contacts with a particular group, in this case with the Russians, can be useful in explaining the diversity of attitudes of respondents toward that community. The overwhelming majority of respondents declared that they did not have personal contacts with Russian citizens (60\% of all respondents) and one in three students had never been to Russia (33\%). Only 14 respondents $(11 \%)$ had visited the country. Onethird replied that they maintained contacts with Russians, that is, that they had relatives, friends or acquaintances in Russia. The answers contained statements emphasising the desire to go to Russia and to establish closer relations with its inhabitants.

While analysing the place of residence of the respondents, it transpired that $93 \%$ of them lived in a city, including $72 \%$ who gave Warsaw as their place of residence, and only $4 \%$ lived in rural areas. Besides Warsaw itself, other areas belonging to the Warsaw agglomeration were indicated. Some respondents came from other regions, namely Podlasie voivodeship (Białystok, Supraśl) and Lublin voivodeship (Lublin, Puławy, Biała Podlaska), but those were single students. The data giving Warsaw as the respondents' place of residence confirm the earlier finding that most students at a university in a city are usually people that were born in the city. This also holds for the University of Warsaw: despite its significance among other universities in the country, it is still dominated by students from the Mazovia region, especially the Warsaw agglomeration.

\section{Results}

\subsection{Evaluation of Polish-Russian relations}

The respondents were asked to assess the relations between Russia and Poland in a closed-end- ed question by ticking an answer on a five-step scale from "very good" to "very bad". It was also possible to enter another option (to describe Polish-Russian relations differently) or to select the response "I don't know." Half of the respondents considered Polish-Russian relations bad, and one in five considered it neutral or found that their character should be evaluated in other categories than those specified in the questionnaire. The latter group of responses also included answers emphasising their ambivalent, emotionally charged nature, often difficult to determine clearly, for example: "neither good nor bad, unnecessarily emotional"; "very complicated, on the border of bad and neutral"; "tense"; "not neutral, but not very good"; "they are not very bad but also not good"; "ambiguous"; "one spark is enough for it to go up in flames," etc. Several people described the Polish-Russian relations as not bad: "getting better, but still cannot be called good"; "on the right track"; "they are good, but the Smolensk catastrophe doesn't narrow the gap and does not improve the relations". It should be noted that some of the surveyed students pointed out factors that caused political relations between the two countries to deteriorate, for example: "they are bad because of Russia's politics and the Smolensk affair, but a couple of psychos are trying to aggravate the relations further"; "the good will is there, but there are also many difficult issues"; "it depends on who is in power at the time, if it's PiS (Law and Justice - a conservative political party in Poland), then they are very bad." Only 9\% of the respondents considered them to be good. The views of the UW students are similar to the statistical data on the opinions of Poles, except that compared with the results of the survey carried out by CBOS in February 2011, the students judged the Polish-Russian relations as bad more often - $50 \%$ vs. $42 \%$. However, it should be noted that the views that Poles hold clearly vary in time. In the past few years the Polish-Russian relations were evaluated best in May 2010, just after the crash of the presidential plane in Smolensk (Research report 2011).

It is possible to notice a pattern in the distribution of answers evaluating Polish-Russian relations by the field of study of the respondents (see Fig. 1).

Thus, Spatial Management students (Faculty of Geography and Regional Studies) evaluated 


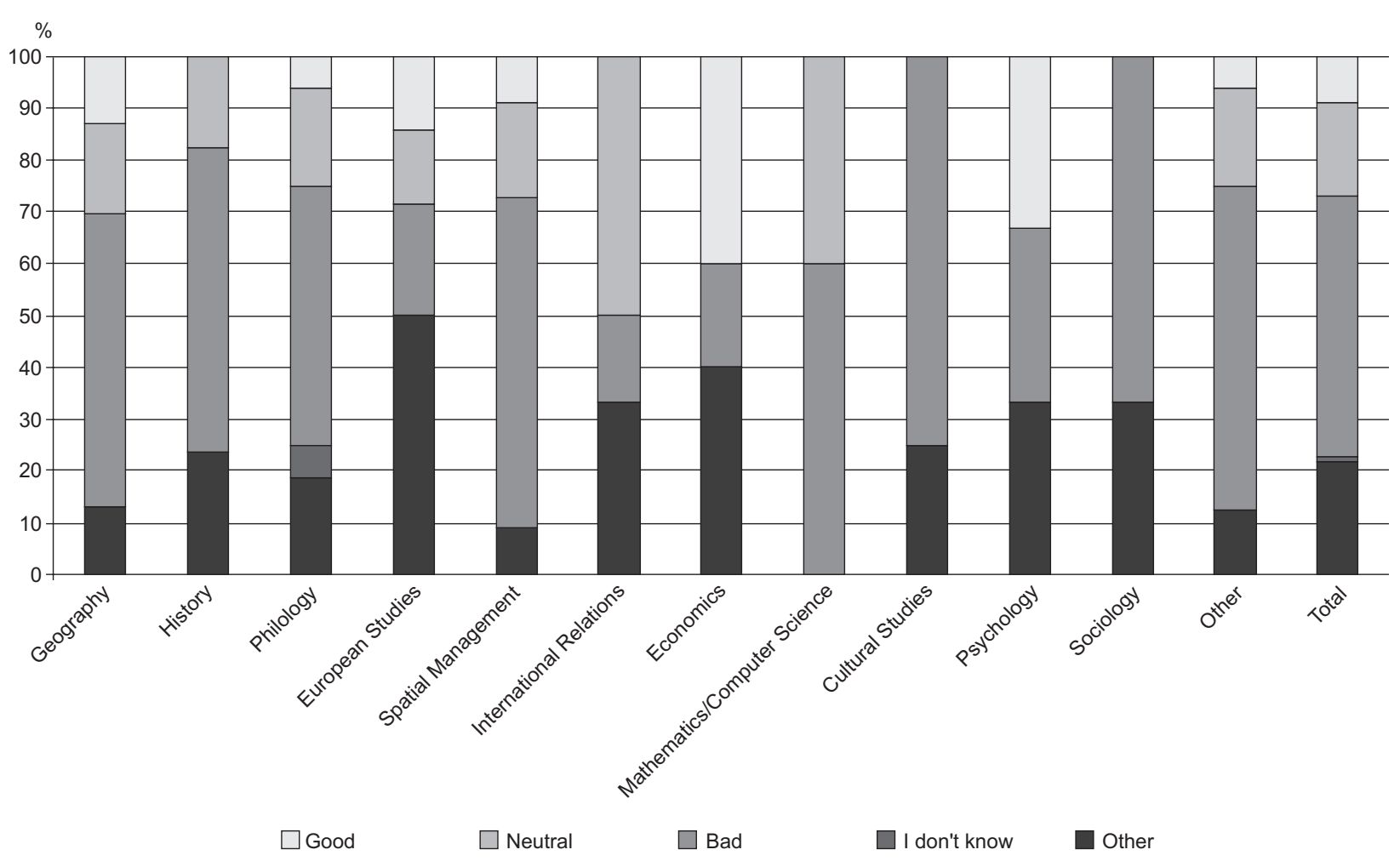

Fig. 1. Assessment of the Polish-Russian relations by UW students, by field of study. Source: own survey.

Polish-Russian relations in the most negative terms $(63 \%$ of responses in this group of respondents) along with History students (59\%) and those of Biology, Geology, Ethnology, Spanish and Portuguese studies, each represented by one person. Possibly the large percentage of History students defining the current Polish-Russian relations as bad was the result of their skewed view of historical events.

Students of Economics, Psychology, European Studies and Geography rated Polish-Russian relations as good. In turn, students of International Relations viewed Polish-Russian relations as neutral, while those majoring in other Europe-related subjects, like Eastern Europe (East European Studies and East Slavic European Studies), most often chose the "other" category of answers, describing the relations as more complicated, complex, and ambiguous (see the sample statements above). It can be assumed that the majors related to Eastern Europe, which include Russian Studies, have a broader knowledge of the realities of contemporary Russia, and thus were able to give other multi-faceted descriptions of Polish-Russian relations.

It seems equally important that the evaluation of Polish-Russian relations was also influenced by personal contacts the respondents had with Russians (Fig. 2). The assessment of the relations strongly depended on whether the participants had Russian friends. Those who declared that they had relatives or friends among Russians rated the relations as good more often than those who did not $(12 \%$ vs. $7 \%)$, or defined them as the "other" category (36\% vs. $16 \%)$.

There were no significant differences in the evaluation of the Polish-Russian relations by the sex of the respondent. Despite the fact that the study included more women than men, their responses were similar.

\subsection{Students' feelings towards Russia and Russian people}

The purpose of the next question was to determine the feelings the respondents had toward Russians. In this question, they were asked again to indicate one of the several possibilities, i.e., "like," "indifferent," "dislike," "no opinion", or give other emotions. Positive responses (i.e., "like") and neutral ones ("indifferent") were similar in number - each approximately 38\% 


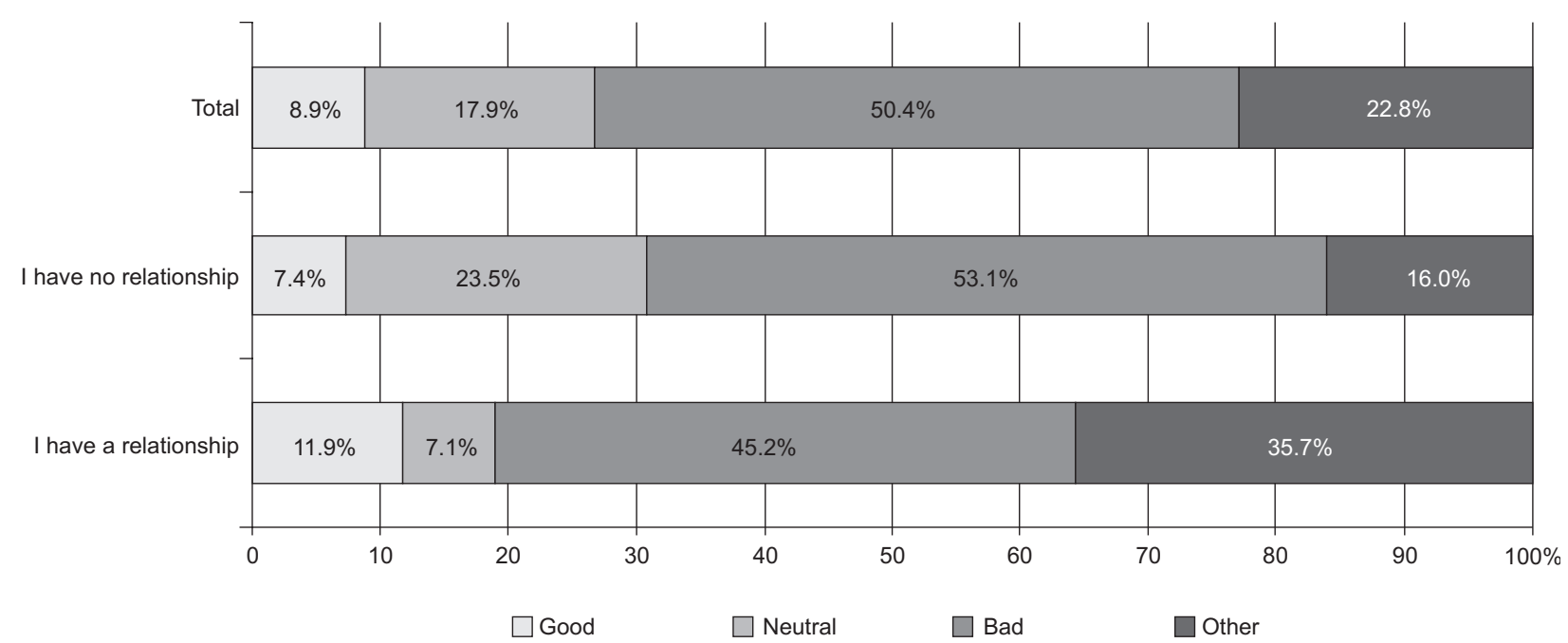

Fig. 2. Assessment of the Polish-Russian relations by UW students, by level of personal involvement with Russians. Source: own survey.

of all valid responses. The smallest group of respondents were those in whom Russians aroused negative feelings - just 9 students $(7 \%)$ responded that Russians triggered a feeling of dislike in them. Several respondents (12\%) defined their attitudes as different than those specified in the questionnaire, describing their feelings as mixed or ambivalent. There were also statements showing a different attitude toward ordinary citizens as opposed to the government of Russia: the attitude toward ordinary Russian citizens was described as positive, while toward the authorities as negative. Some examples of answers to the question "What kind of feelings do the Russians cause in you?" include: "Empathy for the citizens, aversion toward the authorities"; "authorities - negative emotions, people - sympathy"; "maybe with the exception of the authorities they cause negative feelings in me." There were also some responses showing radically negative emotions toward Russians, for example "hatred" and "fear".

In the next question, the respondents were asked to identify three responses from a group of several dozen descriptions or statements pertaining to elements of Russian culture (such as architecture, art, national symbols, engineering and technical objects), contemporary and historical, the natural environment and the socio-political situation that they associated with Russia.

The UW students most commonly associated Russia with "vodka" (14\% of total valid responses), then natural resources such as "natural gas or crude oil" (13\%), as well as religion and architecture, such as "orthodox churches and golden domes" (12\%) (Fig. 3). Next, they associated Russia with the physical dimension and environmental attributes, for example "vast space and freezing cold" (11\%), and an eminent historical Russian personage. The person named most often was Joseph Stalin (7\%). There were stark con-

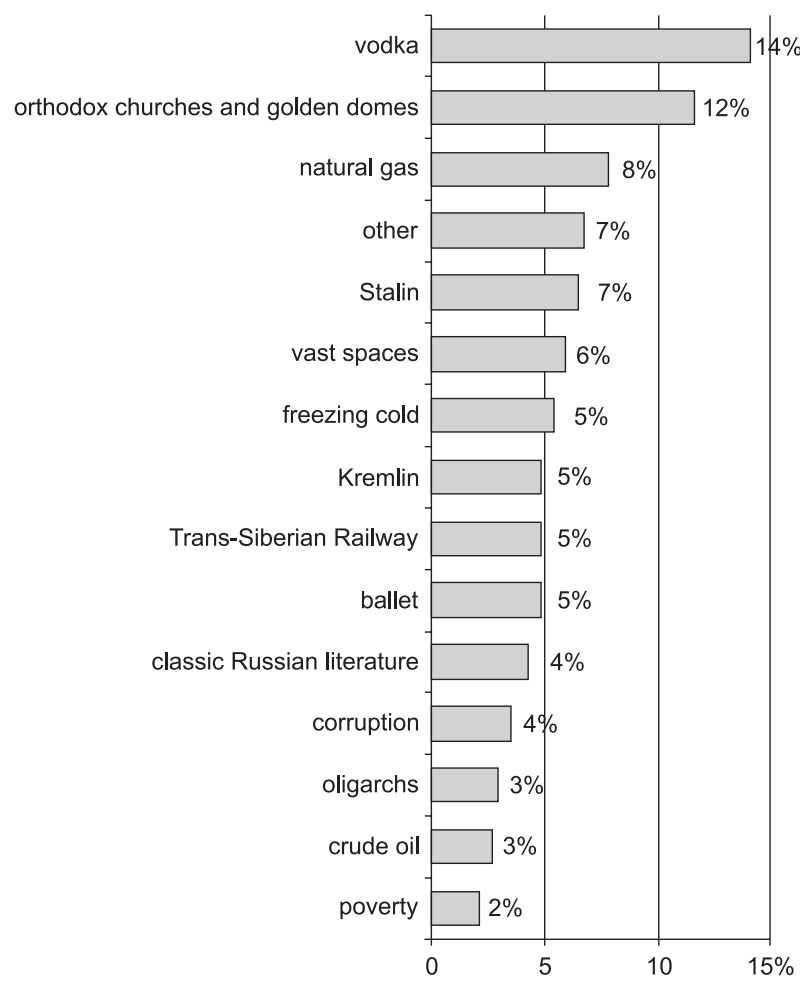

Fig. 3. Students' associations with Russia (as a percentage of total valid responses). Source: own survey. 
trasts in the respondents' answers; on the one hand there were the stereotypical associations, such as vodka, Stalin, corruption, oligarchy, and poverty, but on the other hand, some associated Russia with the characteristic elements of its culture (religion, architecture), art (ballet, classical literature) and the natural environment, such as a harsh climate, a distinctive landscape, and natural resources.

According to de Lazari (2006), the way Poles perceive Russians and Russians perceive Poles is the result of varying 'cultural programming'. Different fates and socio-political situations of the two countries have had the greatest influence on the formation of differences in traditions, and consequently in mentalities.

Comparing the responses of men and women, one may notice a certain regularity. Both groups, and to a similar extent, associated Russia with vodka, classical Russian literature, and a specific socio-political situation, especially corruption and poor living standards. There were, however, quite distinct differences in the perception of Russia by men vs. women (Fig. 4). While women were more likely than men to associate it with ballet, architecture and religion (the Kremlin and orthodox churches), or with specific mineral resources, i.e. natural gas and crude oil, men tended to see Russia in terms of its characteristic natural features (natural resources - not only energy resources, but also vast space), socio-political situation (oligarchy), and the Russian national symbols (the flag and the two-headed eagle). Men also associated Russia more often than women with "communism," "partitions," "Putin," "contrasts" (including social contrasts), "the Russian anthem," "Alexandrov's Choir," "athletes," "Cyrillic alphabet," and "beautiful women."

In a commentary to this question, one of the respondents wrote that it would be easier to say what one does not directly associate with Russia. This statement could be interpreted as expressing

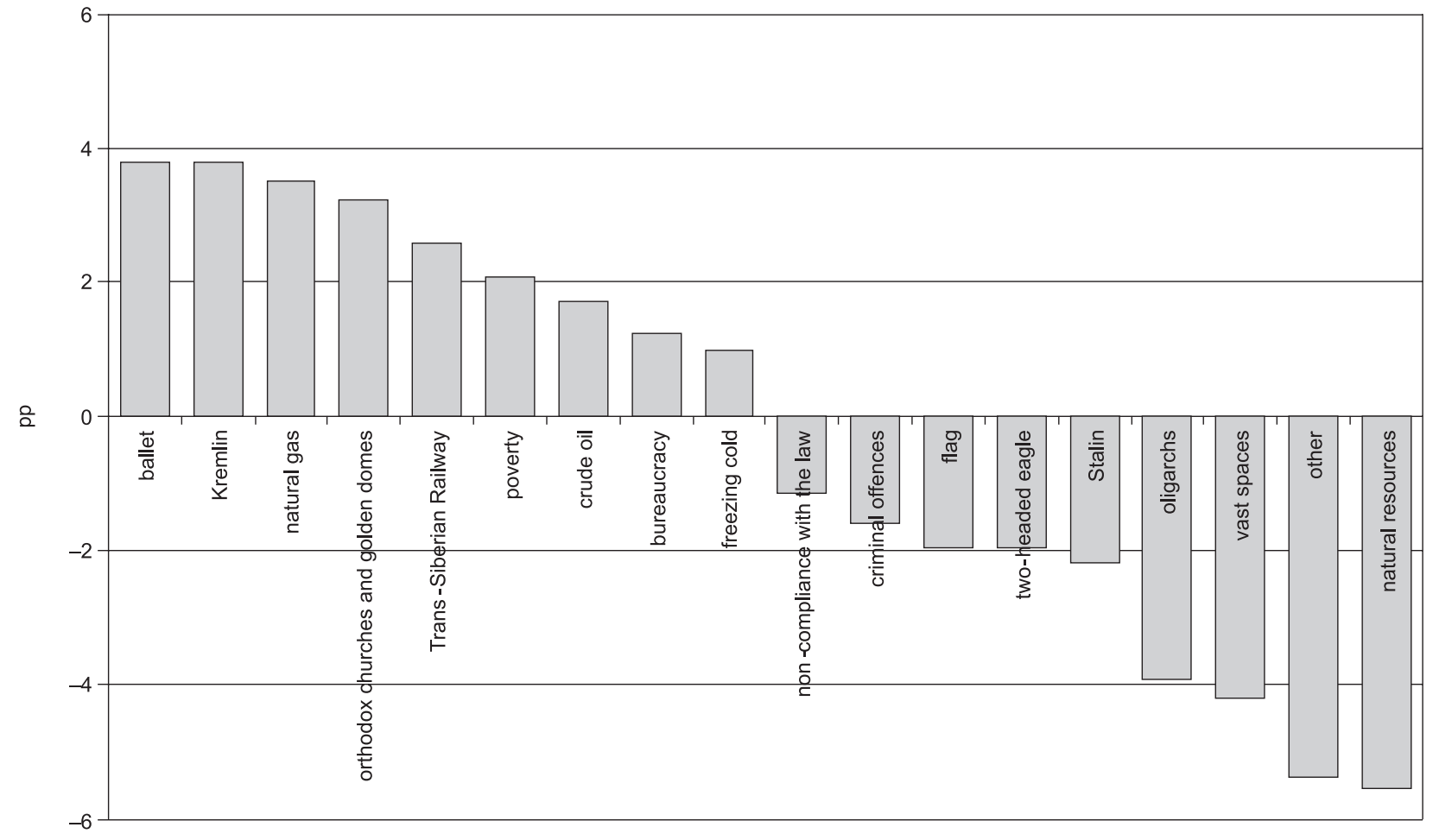

Fig. 4. Differences in men's and women's responses to the question of what they associate with Russia* Source: own survey.

* The data presented in the graph show differences in the percentage of women and men that chose a particular answer. Positive values show that more women than men chose that answer, while negative values show that more men than women chose that answer. For clarity, the graph contains those categories for which the difference in answers was around $1 \%$. 
an opinion about there being a multitude of possible concepts, direct and indirect, that one could associate with Russia.

\subsection{National traits which - in the opinion of students - characterise the mentality of Russians}

To answer the next question, the respondents were asked to choose three answers from each of two groups of personality and mentality traits that they thought were specific to the Russians. In the first group of possible responses (Fig. 5A), containing mostly positive traits, the most often chosen one was hospitality (over 60 responses, i.e. about $16 \%$ ). Next came the belief in a good and just ruler (about $11 \%$ ), openness and warmth (about 15\%), as well as acceptance of suffering and religious devotion (11\%). Although many students associated Russia with art (ballet and classical literature, as shown in the previous question), the attributes of creative people and great artists, like talent or hard work, were indicated relatively rarely.

In the other group of traits (Fig. 5B), drunkenness was chosen most often (over 80 responses, i.e. $23 \%$ ), in line with the responses to the previous question about what students associated with Russia, which confirms that they often have a stereotypical image of Russians. The next most frequently indicated traits were cult of personality $(13 \%)$, radical behaviour: from kindness to cruelty $(10 \%)$, as well as passivity and social apathy $(12 \%)$.

It is noteworthy that in both groups the answers associated with the symbol of power and an attitude toward it are in the second place (chart 5A and 5B). This image of Russian society encoded in Polish consciousness is explained by de Lazari (2006) again by 'cultural programming' . An example illustrating how differently we are 'programmed', which affects the image people have of each other, is the idea of patriotism as expressed in the Polish military motto "God, Honour, Fatherland" and the Russian military motto "God, Tsar and Fatherland" (de Lazari 2006: 15).
A. Positive traits

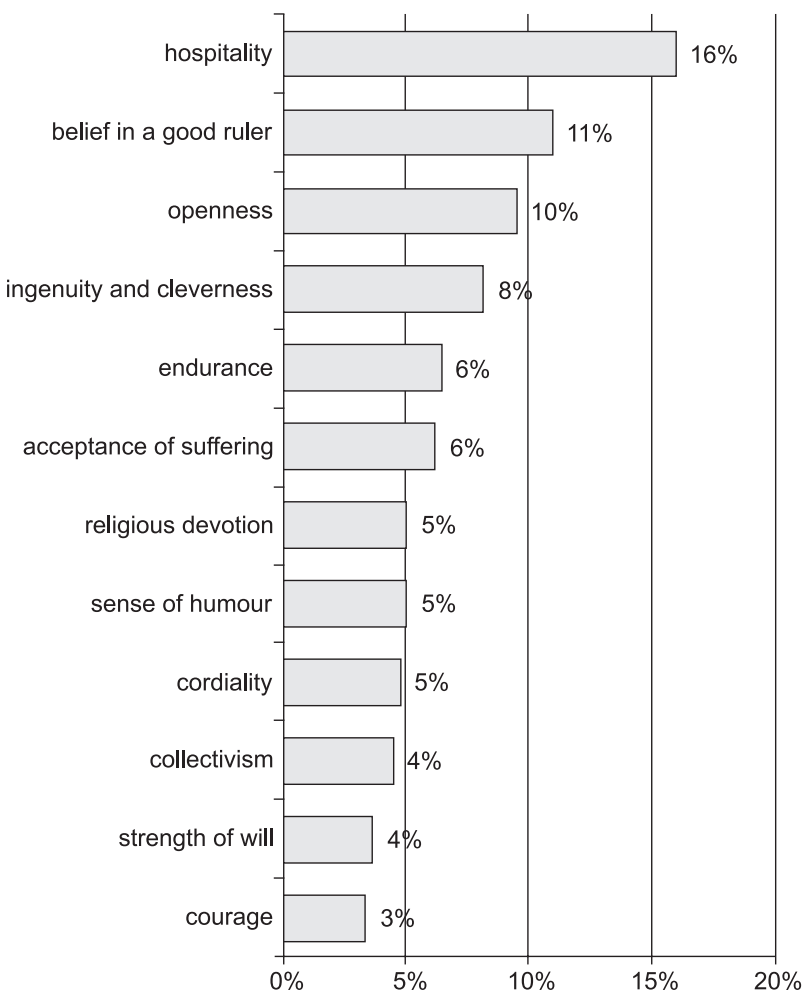

B. Negative traits

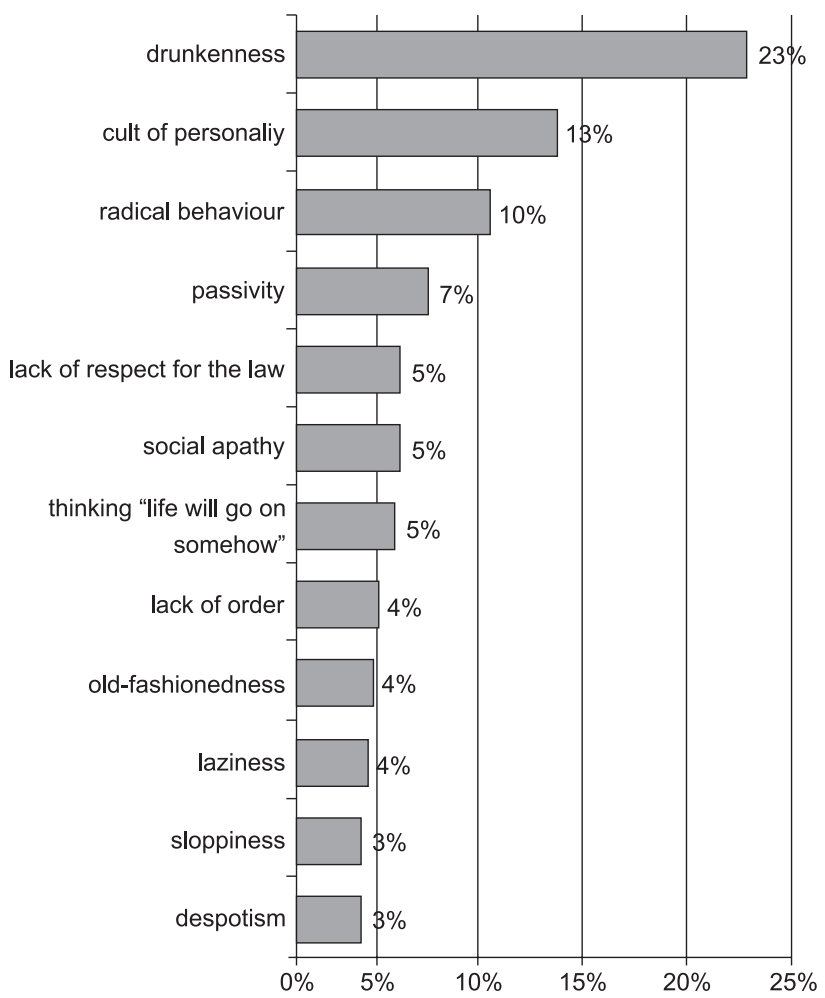

Fig. 5. National traits characterising the mentality of Russians in the opinion of students. Source: own survey. 


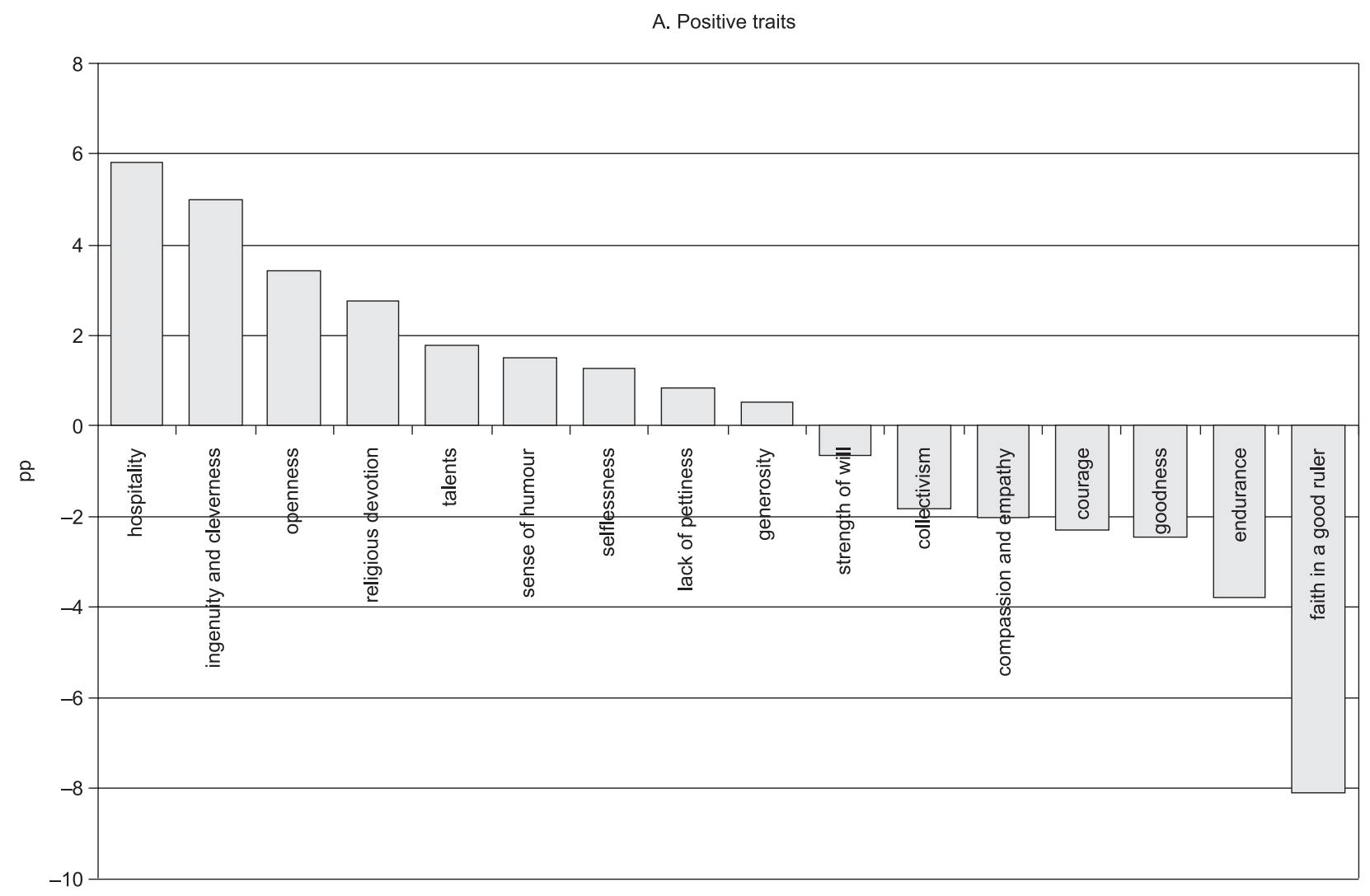

B. Negative traits

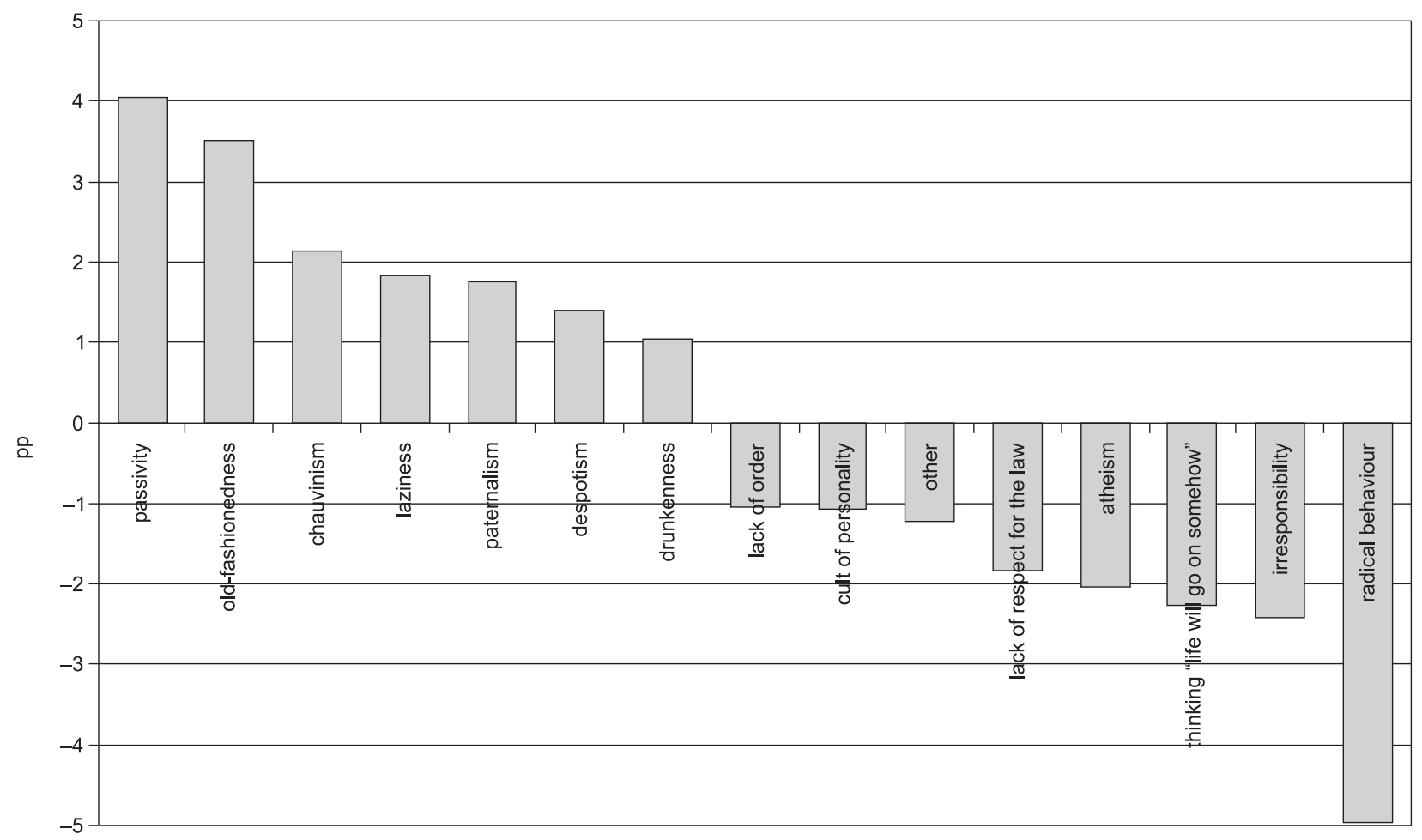

Fig. 6. Differences the answers of men and women about the national traits that characterise the mentality of the Russians. Source: own survey. 
When analysing the distribution of responses by sex of the respondent, other differences are also noticeable (Fig. 6). Women were more likely to consider Russians hospitable - a difference of $6 \%$ (women $-18 \%$, men $-12 \%$ ) - as well as imaginative and clever (of 5\%). They were also more likely to view Russians as open and religious, while men more often chose the answer "belief in a good and just ruler" (16\%). Men also indicated perseverance, courage and collectivism more often than women (Fig. 6A).

In the other group, that of negative traits, the differences in responses between men and women were smaller (Fig. 6B). Women more often chose "passivity" and "old-fashionedness" (a difference of about 4\%), while men more often responded with "behaviour characterised by radical tendencies from kindness to cruelty" (a difference of $5 \%$ ).

\subsection{Evaluation of Polish and Russian mentality}

In answering the question "Do you think there are any similarities in the mentality of Poles and Russians?", a vast majority of respondents, viz. 88 (or $73 \%$ of all valid responses) found common characteristics in the disposition of the two nationalities, only 10 students (or $8 \%$ ) responded that there were no such similarities, and $23(19 \%)$ had no opinion on the matter. The students were also asked to identify those elements of the mentality of Poles and Russians that they believed were common to those two nations. They responded with both, positive and negative traits, the positive ones outweighing the negative ones. The positive traits chosen most often were hospitality (22\% of all valid responses), openness ( $7 \%)$, religious devotion $(4 \%)$, and devotion to family life. Prevailing in the group of traits with negative connotations were propensity for alcoholism $(15 \%)$, laziness (5\%), and sloppiness. It is worth noting that in the opinion of many respondents the propensity for alcoholism characterises both Slavic nations.

The responses often referred to the Slavic (or East Slavic) origin of the two nations and cultures, and pointed out positive traits such as "Slavic hospitality", as well as negative such as
"East Slavic culture that brings to mind vodka and wheeling and dealing." Common traits of both nations, in the opinion of many respondents, were a strong attachment to the present and the acceptance of explicit passivity, which is also expressed by the Slavic saying "life will go on somehow."

According to the respondents, we were also connected by history and a specific personality type, known as Homo sovieticus, that had formed under communism. The communist system moulded the being called Homo sovieticus via superior values, like work, participation in ruling power, and a sense of dignity. But work made man dependent on the state, the participation in ruling power was fabricated, simulated by the feeling of intimacy with what was important, and the sense of dignity was artificially enhanced by the propaganda. A person that came from the common people was held in higher regard than others and was appointed to play a special role in history. Homo sovieticus, with his needs and hopes remaining unmet by the system, contributed to the overthrow of communism (Tischner 1992). The process of disintegration of the political structures occurred quite rapidly, while the transformation of Homo sovieticus takes place at a much slower pace.

Several respondents also referred to the idea of the 'Slavic soul' written about, among others, by Nikolai Berdyaev ${ }^{1}$ (1916), who tried to understand and explain the mutual prejudice between Poles and Russians. Berdyaev, however, looked for the causes of the dissension between the two Slavic nations in spiritual differences that could not be explained solely by objective historical factors and political circumstances: "the Russian soul and the Polish soul are unfortunately still contrasting worlds, alien, distant, not understanding each other. The moment of closeness has not arrived yet; the need for mutual understanding is still lacking" (Berdyaev 1916).

A Russian orthodox philosopher and scholar considered one of the greatest orthodox thinkers of the $20^{\text {th }}$ century. 


\subsection{Knowledge of Russia}

In an open-ended question the respondents were asked to name historical and contemporary Russian personalities known to them, by writing their names down under five categories: science, literature and art, politics, sports, and those related to the armed forces and wars.

In the first category, the students most often named Mendeleev, Gagarin, Pavlov, Lomonosov, and Sakharov. A few were able to identify individual scientists from their own disciplines of study (for example, a Biology major gave Nikolay Pirogov, a Russian surgeon and anatomist and the author of a four-volume atlas of anatomy, and a Mathematics major wrote about Viktor Bunyakovsky, a Russian mathematician and expert in the field of number theory and probability theory, who lectured in the Petersburg Academy of Sciences). It should be noted, however, that a significant proportion of respondents failed to identify even one person (45 people, $37 \%$ of respondents), and a vast majority of the rest of the group named only one person. The limited knowledge of Russian scholars can be explained by the fact that most of the mentioned scientists are already dead. Only a few respondents knew a contemporary Russian scientists, namely Lilia Shevtsova (a Russian political scientist who has been teaching at various American universities since 1992).

From among the representatives of Russian literature and art, the students most often named Alexander Pushkin, Mikhail Bulgakov, Fyodor Dostoyevsky, Anton Chekhov, and Alexander Solzhenitsyn. In this category, only 9 respondents did not provide any answer, and a vast majority listed several representatives of the Russian arts. In addition to the representatives of traditional Russian literature (such as Chekhov and Tolstoy) known to most of those surveyed, a few also named representatives of the contemporary literary scene, for example, the author of a post-apocalyptic novel Metro 2033, Dmitry A. Glukhovsky, describing the lives of people inhabiting the Moscow subway system after a nuclear war.

In the next category the students were asked to name representatives of the Russian political scene, both historical and contemporary. In this case, only two respondents did not give any an- swer, and a vast majority were able to identify a number of politicians who were in power in the tsarist times (Tsars Peter I, Ivan the Terrible, Empress Catherine II), Soviet times (Lenin, Joseph Stalin, Nikita Khrushchev ), as well as currently (Vladimir Putin, Dmitry Medvedev).

From among Russians associated with the armed forces and wars, students named most often participants of tsarist wars, the PolishBolshevik War of 1919-1921, leaders of the Soviet Union, and leading politicians in power in Russia today. In the fist group the students listed, among others, the tsars Vasili IV of Russia, Peter I, and Alexander Nevsky of the Rurik dynasty, who was also Grand Prince of Vladimir and an Orthodox saint. Among Russian participants in the Polish-Bolshevik War, they named Mikhail Tukhachevsky, the tsarist army officer who led an attack on Warsaw in 1920, and Semyon Budyonny, whose First Konarmiya fought in the South-West Front, trying to get to Lviv. As to historical Soviet leaders, the students named Vladimir Lenin and Joseph Stalin, also given were contemporary Russian leaders: Vladimir Putin and Dmitry Medvedev.

The next question was: "What monuments and interesting places in Russia do you know?" It got many different answers. From among natural landscapes, the respondents most often named areas in the Asian part of Russia: Siberia, Lake Baikal, permafrost, Kamchatka, volcano, taiga, tundra, the rivers $\mathrm{Ob}$ and Lena. As to natural landscapes located in the European part, those most popular were the Black Sea coast, Sochi, the Caucasus mountains and the rivers Moskva and Volga.

Many objects located in the former and current capitals of Russia were named in the category of cultural historical landscapes and monuments. Those located in St. Petersburg included the Hermitage Museum and Winter Palace, and in Moscow the students knew the Kremlin, Red Square, Lenin's Mausoleum, St. Basil's Cathedral and the State Tretyakov Gallery. Other cultural historical landscapes given were the Trans-Siberian Railway, churches located in the Golden Ring, Peterhof, and Tsarskoye Selo. A vast majority of the respondents gave more than one answer - a better result than the outcome for the question about natural landscapes. 
When asked about their desire to see a selected place in Russia in the future, "Which sights and interesting places in Russia would you like to see?," they chose in equal parts between areas valuable for their natural environment and those attractive for anthropogenic reasons. Some answers were very general, e.g. "Moscow and most of its monuments," "St. Petersburg the Venice of the North," or "Siberia". Others precisely defined the place they would like to visit on a trip to Russia, for example, "any of the former Closed Cities" (secret settlement centres), or "main MGU Campus" (Moscow State University). There were also a few radically opposite answers, such as "nothing", "anything", or ones that indicated moderation in the choice of potential sites ("a little bit of everything"). A characteristic feature of this question was that only six respondents did not give any answers, which allows the conclusion that, if a voyage to Russia were to come up, the students were aware of quite many potential sites they would like to see.

The last question asked what could serve as a symbol of Poland. The respondents gave widely different answers. Some chose attractive natural areas ("Tatra mountains," "Mazuria region," "Baltic Sea"), some cities ("Warsaw," "Cracow"), some famous Poles, e.g. Frederic Chopin, Copernicus, or Pope John Paul II, and some, symbols of folk culture and alcohol (the vodkas "Zubrowka" and "Wyborowa"). A small proportion of the respondents wrote about positive traits of Polish society ("hospitality," "openness"), and the economic changes after Poland had joined the European Union ("cultural and technological progress, as well as economic progress via the European Union"; "I dream that one day innovative technologies should become the symbol of Poland"). A few respondents mentioned elements that link Poland and Russia directly ("common Slavic roots"; "Polish literature about Russia, such as Ice by Jacek Dukaj, could be promoted"). One of the participants expressed the opinion that the symbol of Poland should be "no anti-Russian sentiments."

\section{Discussion}

The research on how Russia and the Russians are perceived has been conducted and is available also in other European countries, such as France and Germany. Much as in Poland, these studies are conducted by institutions dealing with public opinion surveys (French Opinea, La Russie aux yeux des Français, 2012; FIFG, Les Français et les libertés publiques et le respect des droits de l'homme en Russie, 2013). According the Opinea survey (La Russie ..., 2012), half of the French have a negative opinion and attitude toward Russia, mainly associated with the country's policies. The criticism relates to such fundamental issues as human rights, democracy and the defence of world peace. There is also emphasis on negative behaviour associated with the operation of enterprises, their corruption, and abuse associated with their business activities.

Recently, the research has become more focused on the evaluation of a nation by another by comparing it against other nations. Comparing the opinions of two nations with varied intensity of relations with Russia can yield interesting results and also verify some of the arguments about how Russia is perceived by the two countries. It is also important to look for similarities and differences in mutual impressions between Russia and various nations. They become particularly interesting in the light of the increasing frequency of interactions brought about by globalisation.

The subject of this type of research performed in Germany, Poland and Russia is the perception of an individual nation by the others. The Institute of Public Affairs publishes compelling studies on this subject in its journal People-History-Politics. Poland and Germany in the eyes of the Russians (2012). They show that Russians have a very favourable impression of Germany and the Germans as well as the Russian-German relations. Against this backdrop, the results on Poland, Poles, and the Polish-Russian relations are significantly worse, although Russians do not see Poland and Poles in a negative light. Their opinion can be described as neutral with a dose of sympathy. Personal contacts with Russians appear 
to play a key role in the assessment of Russians by Germans and Poles - they are not too lively, which probably affects mutual impressions.

The Polish students that participated in the present study are open to the surrounding reality, conscious of the mental and spatial proximity that links Poles and Russians, and aware of problems that define the present-day Polish-Russian relations. A vast majority of the participants are people who possess a fairly extensive knowledge of various aspects of life in Russia and expressed sympathy for Russia and the Russian people.

Some statements by certain groups of students revealed a stereotypical understanding of Russia and Russians, indicating a conventional and superficial knowledge of Russian history and culture established in the minds of those young people. In the opinion of the authors, the results of the research presented above may be useful not only at the university level, but also in elementary- and secondary-school education, especially for teachers dealing with socio-cultural, economic, political and geographical European issues.

The conclusions drawn from the survey carried out by the Institute of Public Affairs on the perception of Polish-Russian-German relations could serve as an argument for further research. It follows from publications in People-History-Politics that about one third of the respondents choose "I don't know" to answer the questions asked, which may indicate a negligible knowledge of other nations in Europe. What is more, further research could be inspiring for Germans making Russian comparative studies since it would provide information not only about the perception of their country and society by Russians, but also about how Russians perceive Poland, which is an important partner in implementing EU policies in Eastern Europe.

In terms of the results presented here, it is worth noting how Russians (Russian students) perceive Poland and Poles. The next stage of the research conducted by the authors of this study, in collaboration with representatives of the University of St. Petersburg, will be to compile and compare the opinions of students of both countries on the Polish-Russian relations.

\section{References}

Berdyaev N., 1916. Русская и польская душа (The Russian and the Polish soul). Уmро России, 85. From http://russian.salon24.pl/398435, rosyjska-i-polska-dusza-w-roku-1918 (accessed 12 April 2012).

BUGAJSKI M., 2010. Rosja i Rosjanie w polskiej prasie (Russia and the Russians in the Polish media). Paper presented at the conference Poznawać, Tworzyć, Komunikować in Łódź. From www.uz.zgora.pl/ $\sim$ mbugajsk/ ?file id $=25$ (accessed 12 April 2012).

Komunikat z badań: Opinie o stosunkach polsko-rosyjskich po katastrofie smoleńskiej $i$ działaniach majacych wyjaśnić jej przyczyny (Research report: Opinions on the Polish-Russian relations after the Smolensk catastrophe and the activities intended to explain its causes), 2011. CBOS, Warsaw.

KRAL W., 2006. Polacy w oczach Rosjan na stronie internetowej www.polska.ru. In: de Lazari A., Rongińska T. (eds), Polacy $i$ Rosjanie - przezwyciężanie uprzedzeń. Wydawnictwo Ibidem, Łódź.

De LAZARi A., 2004. Dusza polska i rosyjska (od Adama Mickiewicza i Aleksandra Puszkina do Czesława Miłosza i Aleksandra Sołżenicyna) (The Polish and the Russian soul: From Adam Mickiewicz and Alexander Pushkin to Czesław Miłosz and Alexandr Solzhenitsyn). In: de Lazari A. (ed.), Materiaty do "katalogu" wzajemnych uprzedzeń Polaków i Rosjan. PISM, Warszawa.

De LazAri A. (ed.), 2006. Katalog wzajemnych uprzedzeń Polaków i Rosjan. Wstęp (The catalogue of mutual prejudices among Poles and Russian. Introduction). PISM, Warszawa.

La Russie aux yeux des Français, 2012. Opinea. From http:// www.opinea.com/actus-etudes/ image-de- la-russie-aupres-des-francais/.

Les Français et les libertés publiques et le respect des droits de l'homme en Russie, 2013. IFOP, Russie Libertés. From http://www.ifop.com/ ?option $=\mathrm{com}_{-}$publication\&type $=$ poll\&id $=2175$.

Ludzie-Historia-Polityka. Polska i Niemcy w oczach Rosjan (People-History-Politics. Poland and Germany in the eyes of Russians), 2012. Instytut Spraw Publicznych, Warszawa.

OrŁowski R., 2006. Rosja i Rosjanie w oczach Polaków (Russia and Russians in the eyes of Poles). In: de Lazari A., Rongińska T. (eds), Polacy i Rosjanie - przezwyciężanie uprzedzeń. Wydawnictwo Ibidem, Łódź.

REMNICK D., 1997. Resurrection: The struggle for a new Russia. Random House, New York.

SKORUPSKA A., 2006. Wizerunek Rosji i Rosjan w mediach (The image of Russia and Russians in the Polish media). In: de Lazari A., Rongińska T. (eds), Polacy i Rosjanie przezwyciężanie uprzedzeń. Wydawnictwo Ibidem, Łódź.

SZTABIŃSKI F., 1997. Ankieta pocztowa i wywiad kwestionariuszowy (Mail-in survey and questionnaire interview). Wyd. Instytutu Filozofii i Socjologii Polskiej Akademii Nauk, Warszawa.

TischNeR J., 1992. Etyka solidarności oraz Homo sovieticus (The ethics of solidarity and Homo sovieticus). Wydawnictwo Znak, Kraków. 